\title{
Influence of Information Literacy Skills on Postgraduate Students' Use of Electronic Resources in Private University Libraries in South-West, Nigeria
}

\author{
Pauline Oghenekaro Adeniran1, Uloma Doris Onuoha² \\ ${ }^{1}$ Redeemer's University, Ede, Nigeria \\ ${ }^{2}$ Adeleke University, Ede, Nigeria \\ Email: omedop2006@yahoo.com, adeniranp@run.edu.ng,ud_onu@yahoo.com
}

How to cite this paper: Adeniran, P.O. and Onuoha, U.D. (2018) Influence of Information Literacy Skills on Postgraduate Students' Use of Electronic Resources in Private University Libraries in South-West, Nigeria. Communications and Network, 10, 164-179.

https://doi.org/10.4236/cn.2018.104014

Received: April, 26, 2018

Accepted: October, 31, 2018

Published: November, 2, 2018

Copyright $\odot 2018$ by authors and Scientific Research Publishing Inc. This work is licensed under the Creative Commons Attribution International License (CC BY 4.0).

http://creativecommons.org/licenses/by/4.0/

\begin{abstract}
The introduction of new technologies has had a significant influence on teaching, learning and research activities in universities. This has offered university libraries opportunities to provide information resources in a variety of formats. This study investigated the influence of information literacy skills on postgraduate students' use of electronic resources in private university libraries in Nigeria. The study adopted the survey research design. The study population comprised 2805 postgraduate students in five private universities offering postgraduate programmes in South-West, Nigeria. Multistage sampling technique was used in the selection process. A purposive selection of four faculties from each of the five universities was carried out. Proportionate sampling technique was used to select the sample size of 550 postgraduate students as the respondents for the study. Findings revealed that there was a significant positive correlation between information literacy skills and use of electronic resources $(r=0.28, p<0.05)$. The study concluded that the utilization of electronic resources promoted access to current information among postgraduate students in the selected private universities in South-West, Nigeria. The study recommended that the management of private university libraries should ensure a continuous provision of electronic resources with adequate information communication technology tools to facilitate their use.
\end{abstract}

\section{Keywords}

Information Literacy, Electronic Resources, ICT Skills, Academic Performance 


\section{Introduction}

In the past, most university libraries provided information in print format such as print textbooks, newspapers, monographs, magazines and so on, but with the advancement in technology, most libraries have expanded their collections to include electronic resources abbreviated as e-resources. In The Anglo-American Cataloguing Rules, Second Edition [1] defined an electronic resource as "material (data and/or program(s)) encoded for manipulation by a computerized device. This material may require the use of a peripheral directly connected to a computerized device (e.g., CD-ROM drive) or a connection to a computer network (e.g., the Internet)". The International Federation of Library Associations and Institutions [2] defined e-resources as "materials that require computer access, whether through a personal computer, mainframe, or handheld mobile device". From the definitions, it can be deduced that electronic resources require the knowledge and use of computers.

The provision of electronic resources in university libraries plays a prominent role in facilitating access to required information by the users in an easy and quick manner. Electronic information resources, in reality, have become essential in the academic environment. They serve as motivating factor to students as they provide the opportunity to transmit, acquire or download process and disseminate information on any subject of interest. Electronic resources provision makes it possible for users to access new tools and applications for information seeking and retrieval. E-resources have become invaluable research tools that complement the print collection in the traditional library setting. These resources serve as veritable sources of information which students could tap into to aid their class assignments, write research and term papers, and search for information on their subject areas and so on.

Due to the several advantages of e-resources such as timeliness, search facilities, remote access and up datedness, they become more indispensable after the arrival of the Internet in the academic environment. The provision of e-resources in tertiary institutions of learning is a new way of gaining quick access research information globally. As a result of the potential benefits offered by e-resources, they have been embraced by university libraries. Students, especially those at the postgraduate level would benefit from the e-resources if they are well harnessed as they will provide excellent opportunities to access scholarly information which is beyond the reach of libraries due to geographical barrier and limited finances. To be successful in the use of the available e-resources, students need to acquire and practice the skills necessary to explore them. Therefore, for effective information search to be achieved by postgraduate students, computer literacy is crucial.

\section{Statement of the Problem}

In Nigeria, the university system is advancing as new technologies are being introduced into teaching, learning and research activities. On their part, university 
libraries must support the mission of the university through the provision of information resources in a variety of formats including electronic format. While the provision of electronic resources in libraries no doubt has myriad advantages as it enables access to current information at the right time and in the right place, provides the opportunity to search several files at a time and so on, it also presents a lot of challenges as it is computer-based and requires information literacy for searching, retrieval, and use.

Literature has revealed that electronic resources are grossly underutilized despite the huge investment made by university libraries to ensure their provision. [3] observed that considerable investments are being tailored toward acquiring e-resources in Nigerian universities bringing up the issue of the extent of usage and users' satisfaction with these resources in these libraries. Studies by [4] and [5] revealed that practical uses of e-resources are not up to the worth in comparison to investments made in acquiring these resources. The underutilization of e-resources could be attributed to lack of information literacy which limits the ability to effectively locate and make ethical use of needed.

Where such is the case, libraries in private universities which do not receive any form of financial assistance from the government would find it difficult justifying the investment on electronic resources and their contribution towards achieving the goals of the library. At the same time, postgraduate students would also be missing out in research materials that would have otherwise improved the quality of their research work thereby lowering the standard of research work and contribution to the society as a whole. It is against this background that this study investigated the extent to which information literacy skills could influence e-resources utilization by postgraduate students in private universities in South-West, Nigeria.

\section{Objective of the Study}

The specific objectives of the study are to:

1) find out the purpose(s) of use of e-resources by postgraduate students in private universities in South-West, Nigeria;

2) determine the frequency of use of e-resources by postgraduate students in private universities in South-West, Nigeria;

3) ascertain the level of information literacy skills of postgraduate students in private universities in South-West, Nigeria;

4) determine the relationship between information literacy skills and e-resources use by postgraduate students in private universities in South-West, Nigeria.

\section{Research Questions}

The study provided answers to the following research questions:

1) For what purpose do postgraduate students in private universities in South-West, Nigeria use e-resources?

2) What is the frequency of use of e-resources by postgraduate students in pri- 
vate universities in South-West, Nigeria?

3) What is the level of information literacy skills of postgraduate students in private universities in South-West, Nigeria?

4) What is the relationship between information literacy skills and electronic resources use by postgraduate students in private universities in South-West, Nigeria?

\section{Hypotheses}

The study was guided by the following null hypothesis:

$\mathrm{H}_{01}$. There is no significant relationship between information literacy skills and e-resources use by postgraduate students in private universities in South-West, Nigeria

\section{Literature Review}

As new technologies are introduced, the skills that are required to explore them by users must evolve. Information and communication technologies have changed the expectations and demands of library users and the skills and training that the users need have also evolved [6]. In higher education, students who possess information skills particularly now that the volume of information has greatly increased will achieve maximum performance with the use of e-resources. [7] described technology as the systematic application of scientific knowledge in order to achieve practical results. It implies that technology is all about methods and the way people apply them in order to get results. In the competitive environment where things are changing fast and for the better technologically, there is a need for skills acquisition to facilitate access to gain benefit in the ICT environment.

Information literacy is a tool which enables learners to master content and extend their investigations, become more self-directed and assume greater control over their own learning. Information literacy is key to benefiting from the information revolutionized society. [8] asserted that scholarly communication is impossible without implementation of IL skills-scholars from all disciplines have to know how to search for information, how to evaluate it, how to produce and present new information in a proper, ethical manner. [9] noted that lack of information search skills leads to delay and frustration in students' attempt to complete courses related works that require research. Lack of the basic skills to use available e-resources adversely affects the academic performance of students as well as their research output in the information era.

Information literacy competency standards for higher education is characterized by: the information literate student determines the nature and extent of the information needed; the information literate student accesses needed information effectively and efficiently; the information literate student evaluates information and its sources critically and incorporates selected information into his or her knowledge base and value system; the information literate student, indi- 
vidually or as a member of a group, uses information effectively to accomplish a specific purpose; the information literate student understands many of the economic, legal, and social issues surrounding the use of information and accesses and uses information ethically and legally. [10] noted that the concept of information literacy presupposes that a person recognizes when information is needed, have the ability to find, scrutinize, utilize and then use information ethically to address identified problems or to make decisions.

Although most postgraduate students can be said to own a laptop, iPad or mobile phone which exposes them to the use of technology, [11] argued that the use of such electronic devices do not guarantee knowledge of information literacy skills needed to access web-based resources or electronic databases in the library. Students need information for a variety of activities in the university and the e-resources are capable of meeting their needs. Information resources are being exploded daily and there is the challenge of using these resources effectively. [12] observed that in using the e-resources, students lack skill in locating and evaluating information, which impedes their effective use. The author suggested that, libraries should organize orientation programmes in the beginning of each session where the users can be taught how better they can access e-resources and be familiarized with the electronic environment.

The possession of appropriate information search skills enables students to benefit from the vast quantities of information available electronically. [13] observed that the importance of information literacy is even more important than ever before due to the increasingly complex world in which we live now contains an abundance of information choices-print, electronic, image, spatial, sound, visual, and numeric. [14] saw information literacy as a set of information needed for searching, retrieval, evaluation, and making the best use of information. [15] described information literacy skills as the ability to make efficient and effective use of information resources, and that an information literate person today should possess specific online searching skills, which include the ability to select appropriate search terminology, construct a logical search strategy, and evaluate information appropriately.

In recent times, calls are being made to improve the educational curriculum improvement of the quality of education to train students sufficiently to adapt to the $21^{\text {st }}$ century workplace

[16]; [17] argued that literacy is fundamental to national development, and thus nations subscribe to global literacy development agendas so as to eliminate illiteracy which often affects social development. The authors mentioned that individuals need to be adequately and functionally literate in order to be fully capable of living healthy, enjoying a long life and participating in the information driven and digital world. Information literacy helps to define a problem, find information to solve the problem. The acquisition of information literacy skills in society is important today that, the consequences for reaching adulthood with limited information literacy skills are becoming increasingly severe [18] in- 
dividuals who are unprepared to participate in our information-rich society are at an increasing disadvantage, the authors reiterated.

[19] studied the effect of information literacy on the use of library and found that there is a positive relationship. However, the study of [20] found that information literacy instruction did not increase the usage of the library. [21] revealed that information literacy significantly influenced library usage among undergraduates. [22] found that information literacy impacts use of library resources and in the long run higher education performance. Students who possess information search skills in today information technology world are more likely to engage in the use of e-resources to improve the quality of their academic work.

The study of [23] investigated information retrieval skills and use of library electronic resources by university undergraduates in Nigeria. The survey design was adopted for the study that attempted to find out the validity of the assumption that there is no significant relationship between retrieval skills and undergraduates' use of electronic resources in university libraries. It was found that there is a relationship between the two variables, retrieval skills 1) Informational retrieval, 2) Operational retrieval and 3) Strategic retrieval) and undergraduates' use of electronic resources in university libraries. The study found that the relationship between respondents' informational retrieval skills and use of electronic resources was positive, weak and significant $(r=0.242 ; \mathrm{p}<0.05)$. The knowledge of just one or two of the retrieval skills may not adequately assist in undergraduates' use of electronic resources. Likewise, [24] indicated that to effectively retrieve information that users have to interact with data/information, knowledge, concept/term, format, item/objects/site, process/status, location, system, and human.

An investigation of postgraduate students information literacy skills at Babcock University carried out by [25] affirmed that postgraduate students have a moderate level of information literacy skills, even though majority indicated difficulty accessing and retrieving information from external databases, as well as using the online public access catalogue. The study of [26] investigated the effect of information literacy on the utilization of electronic information resources in selected academic and research institutions in Uganda. Data were collected for the study using interviews to both library staff and users of the selected institutions. The results of the study show that some of the available resources have not been utilized at all. This may mean that the participants lack the knowledge of how to access the resources, or they do not know the benefit of utilizing e-resources. [27] also found that limited time and lack of effective information retrieval skills are the main barriers to using e-sources. Information literacy is very vital in influencing utilization of e-resources. The information literacy skills course equip students with the necessary skills and knowledge to enable them to use the library's information resources effectively, legally and ethically and also engage in lifelong learning.

[28] conducted a study on Information Literacy Evaluation. The study aimed 
at evaluating the effectiveness of the Information Literacy Skills course on the use of various information formats at the Africa University. The survey research design was employed by researchers. The questionnaire instrument was distributed to 150 students in 6 Faculties of which 76 were returned and used for analysis. The findings of the study revealed that e-resources usage is a practice that is still in its infancy at the University. This indicates that skills required in using electronic information resources among undergraduate students seem to be limited. [28] observed that some students lacked knowledge on how to effectively use e-journals and e-books in university libraries. [29] carried out in a study on the use of electronic resources in Obafemi Awolowo University and reported very low usage of electronic resources. The major reason reported to contribute to the low utilization of electronic resources was limited searching skills. [30] also enumerated lack of accessibility to computers connected to the Internet; low Internet bandwidth and unreliable power supply as factors contributing to underutilization of electronic resources in university libraries.

[31] investigated the relationship between information literacy and use of e-resources by postgraduate students of the University of Ibadan. The study was aimed at determining the level of electronic information literacy skills possessed by the postgraduate students of the university; investigate what kind of electronic resources are available to postgraduate students of the university; determine the level of usage of electronic information resources by the postgraduate students for academic purposes and lastly, to find out the relationship between information literacy skills of postgraduate students. The survey design was used while questionnaire was used for data collection. The study found that over two-third of the postgraduate students' information literacy skills level is high. The result of the study revealed that internet use skills ranked high among postgraduate students of the University of Ibadan. This indicates that postgraduate students of the University of Ibadan can surf the internet without any difficulty.

[32] conducted a study on the use of electronic information resources by students of Federal University of Agriculture, Abeokuta, Ogun State, Nigeria. This study aimed to investigate the usage of electronic information resources by the respondents. Using the descriptive survey research approach, the simple random sampling was used to select participants from among the students came to use the library during the study period. The instrument used for data collection was a questionnaire tagged: Usage of Electronic information resources. A total of 200 questionnaires were administered, of which 184 were duly filled giving a response rate of $92 \%$. The findings revealed that $92.4 \%$ of the respondents had used electronic information resources, with $51.8 \%$ of them being frequent users. The major electronic resources used by students were internet search engines, e-lecture notes and e-books and they use them for completing class assignments, to obtain course related materials and to keep abreast of latest development in their field. The major barriers hindering effective use of electronic resources were insufficient skills, difficulty in finding relevant information and frequent 
power outage. Training students in information searching skills by the library; the provision of networked computers in Departments and Colleges and lecturers giving assignments that require the use of electronic resources were recommended to ensure effective use of the resources by the students.

\section{Theoretical Framework}

The Big Six information skills model developed by Eisenberg and Berkowitz in 1990, was adopted for this study (Figure 1).

The Big 6 information skills Model developed by Eisenberg and Berkowitz in 1990 , is a 6 stage model to help people solve problems or make decisions using available information. Each of the six steps has two sub-skills. Task definition requires students to identify the exact information problem presented to them. They must also identify the types of information needed in order to solve the problem. They must have a clear hypothesis, a specific question, and a clear understanding of what is needed in order to answer that question. The information seeking strategies stage requires students first to identify all the possible sources of information, and then to evaluate each source to determine which are best for them to use.

The next two steps, location and access and use of information, are comprised of traditional bibliographic skills. Students must not only find individual resources such as books, magazines, reference materials, and Web sites, but also find the information within each source through the use of tables of contents, indexes, and other resource-specific tools. Next, they must engage each source (read, view or listen) and extract specific information from it through the application of note-taking, highlighting, and summarizing. Synthesis requires students to make a decision, create a product, or formulate an answer. Synthesis is linked to task definition in that students are expected to answer the specific question they created when initially engaging in the problem-solving process. Finally, evaluation requires students to evaluate not only their final product but also to evaluate how well they perform the information solving tasks.

A critical look at various models of information literacy proves that information literacy is crucial when it comes to usage of library resources. Therefore, as an important independent variable in e-resources utilization, the Big 6 Information Skills Model propounded by Eisenberg and Berkowitz in 1990 will serve as one of the pillars this research work will anchor on. The reason being that, the Big 6 Information Skills Model of Eisenberg and Berkowitz is more encompassing in terms of information access and utilization.

This model is relevant to this research work because it is concerned with the use of information. The model connects information search and use skills with technology tools in a systematic manner to find, use, apply, and evaluate information for specific needs and tasks. Consequently, the use of e-resources by postgraduate students and the extent to which they use them will depend on 


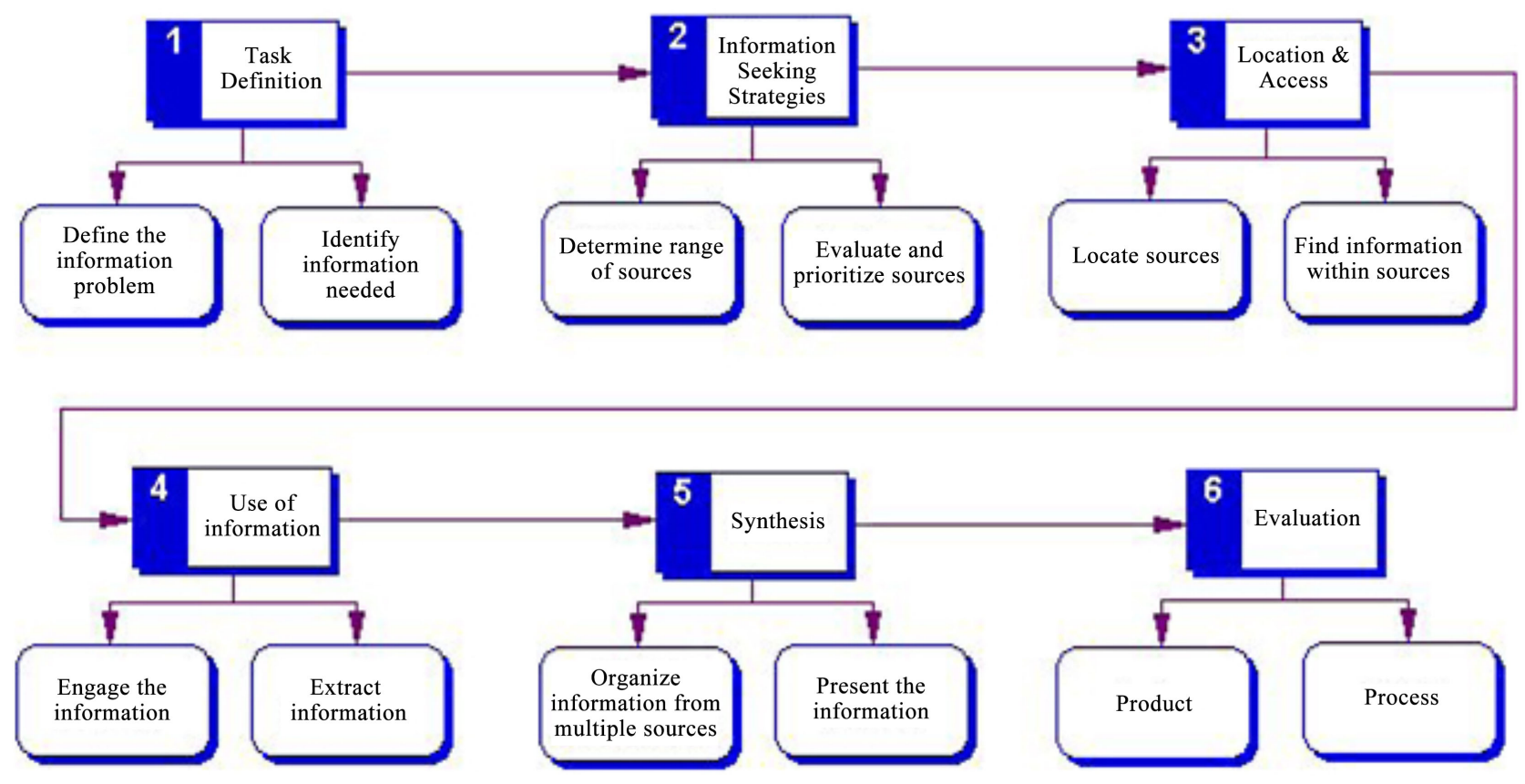

Figure 1. The big six information skills model (EISENBERG \& Berkowitz, 1990).

their ability to define information need, locate information, evaluate and apply it appropriately to meet the academic purposes such as: writing research and term papers, doing assignments, augmenting class works and sourcing for information in subject areas.

\section{Conceptual Model}

\section{Information Literacy Skills}

Ability to:

Identify

Locate

Select

Evaluate

Use/apply Information

\section{E-resources Use}

Internet

E-journal

E-book

Online Databases

OPAC

CD-ROM

The model describes the relationship between the variables; information literacy skills, electronic resources use. It is assumed by this study that postgraduate students who have the ability to identify, locate, select, evaluate and apply information will use the electronic resources provided by the university library. In other words, the use of e-resources is dependent on information literacy skills.

\section{Methodology}

The survey research design of correlation type was adopted for this study. The multi-stage sampling technique was adopted to select the sample for the study. A purposive selection of four (4) faculties/schools/colleges (Education, Humanities, Science and Social Science) was carried out. Lastly, the proportionate ran- 
dom sampling technique using $20 \%$ fraction was used to select the respondents from the departments in the selected faculties/schools/colleges. Thus a total of 550 out of 4212 were selected. A questionnaire was used to collect data. Data collected were analyzed using descriptive and inferential statistics. The hypothesis was subjected to inferential statistics using Pearson Product Moment Correlation (PPMC) analysis (Table 1).

\section{Results and Discussion}

\subsection{The Purpose for Which Postgraduate Students Utilize Electronic Resources}

To find out the purpose(s) for which postgraduate students in private universities in South-West, Nigeria utilize e-resources, the respondents were provided with various questions in the questionnaire and were requested to indicate the purposes for which they utilize e-resources. The mean and standard deviation of their responses were calculated and presented in Table 2.

Table 2 reveals the various purposes for which the respondents utilize e-resources. The average mean score and standard deviation for the entire items in the Table 2 is 3.16 and 0.76 respectively.

However, as shown in Table 4.2, using the Internet to source materials and information $(\bar{x}=3.34)$; using the Internet for research $(\bar{x}=3.29)$; using e-journals to augment class works ( $\bar{x}=3.29$ ); using e-journals for writing term papers $(\bar{x}=3.29)$ were ranked high for purpose of use of e-resources by the participants. On the average, the respondents use online databases for searching information $(\bar{x}=3.23)$ while they used electronic journals for research $(\bar{x}=$ 3.15). The lowest point as indicated in the Table, are: using electronic books to complement class notes $(\bar{x}=3.05)$; using CD-ROM for assignements $(\bar{x}=$ 3.05); and to follow blog discussions on subject area of interest via the Internet access for information $(\bar{x}=3.00)$.

\subsection{The Frequency of Use of Electronic Resources by Postgraduate Students}

To establish the frequency of electronic resources usage by postgraduate students, the options of; "Daily", "Twice a week", "Once a week", "Occasionally" and "Never" were provided for the respondents to choose the one that was applicable to them. Their responses are presented in Table 3.

Table 1. Study population.

\begin{tabular}{cccc}
\hline S/N & Institution & No of PG Students & Sample Size per University \\
\hline 1 & Babcock University & 1994 & 1400 \\
2 & Caleb University & 324 & 125 \\
3 & Covenant University & 1589 & 1036 \\
4 & Redeemer's University & 98 & 87 \\
5 & Lead City University & 207 & 104 \\
& Total & $\mathbf{4 2 1 2}$ & $\mathbf{2 7 5 2}$ \\
\hline
\end{tabular}


Table 2. Purpose of electronic resources utilization.

\begin{tabular}{|c|c|c|c|c|c|c|c|c|c|c|c|}
\hline S/N & Purpose of Use of E-resources & SA & $\%$ & A & $\%$ & $\mathrm{D}$ & $\%$ & SD & $\%$ & Mean & SD \\
\hline 1 & $\begin{array}{l}\text { I use the Internet in the library to source } \\
\text { materials and information }\end{array}$ & 221 & 45.9 & 207 & 42.9 & 47 & 9.8 & 6 & 1.2 & 3.34 & 0.70 \\
\hline 2 & I use the Internet for research & 210 & 43.6 & 212 & 44.0 & 49 & 10.2 & 10 & 2.1 & 3.29 & 0.72 \\
\hline 3 & $\begin{array}{l}\text { I use the e-journals provided by the library } \\
\text { to augment my class works }\end{array}$ & 200 & 41.5 & 229 & 47.5 & 40 & 8.3 & 10 & 2.1 & 3.29 & 0.71 \\
\hline 4 & E-journals for writing term papers & 186 & 38.6 & 251 & 52.2 & 36 & 7.5 & 7 & 1.5 & 3.28 & 0.66 \\
\hline 5 & $\begin{array}{l}\text { I use online databases for searching } \\
\text { information to augment my class notes }\end{array}$ & 170 & 35.3 & 258 & 53.5 & 49 & 10.2 & 4 & 0.8 & 3.23 & 0.66 \\
\hline 6 & $\begin{array}{l}\text { I use the electronic journals provided by the } \\
\text { library for my research }\end{array}$ & 171 & 35.5 & 222 & 46.1 & 68 & 14.1 & 18 & 3.7 & 3.15 & 0.80 \\
\hline 7 & $\begin{array}{l}\text { I use the online databases provided by the } \\
\text { library for my Research }\end{array}$ & 163 & 33.8 & 224 & 46.5 & 75 & 15.6 & 18 & 3.7 & 3.11 & 0.80 \\
\hline 8 & $\begin{array}{l}\text { I use the online database in the library for } \\
\text { my assignments }\end{array}$ & 162 & 33.6 & 219 & 45.4 & 78 & 16.2 & 18 & 3.7 & 3.10 & 0.81 \\
\hline 9 & $\begin{array}{l}\text { I use OPAC for locating materials for } \\
\text { assignments }\end{array}$ & 155 & 32.3 & 234 & 48.5 & 72 & 14.9 & 18 & 3.7 & 3.10 & 0.81 \\
\hline 10 & $\begin{array}{l}\text { I use the electronic catalogue (OPAC) for } \\
\text { sourcing information in the library }\end{array}$ & 157 & 32.5 & 212 & 44.0 & 96 & 19.9 & 17 & 3.5 & 3.06 & 0.82 \\
\hline 11 & $\begin{array}{l}\text { I use the electronic books provided by the } \\
\text { library to complement my class notes }\end{array}$ & 151 & 31.3 & 228 & 47.3 & 78 & 16.2 & 24 & 5.0 & 3.05 & 0.82 \\
\hline 12 & I use CD-ROM for assignements & 144 & 29.9 & 237 & 49.2 & 74 & 15.4 & 24 & 5.0 & 3.05 & 0.81 \\
\hline \multirow[t]{2}{*}{13} & $\begin{array}{l}\text { I follow blog discussions on subject area of } \\
\text { interest via the Internet access for } \\
\text { information }\end{array}$ & 129 & 26.8 & 250 & 51.9 & 71 & 14.7 & 30 & 6.2 & 3.00 & 0.82 \\
\hline & Total & & & & & & & & & 3.16 & 0.76 \\
\hline
\end{tabular}

$\mathrm{SA}=$ Strongly Agree, $\mathrm{A}=$ Agree, $\mathrm{D}=$ Disagree, $\mathrm{SD}=$ Strongly Disagree .

Table 3. Frequency of use of electronic resources.

\begin{tabular}{cccccccc}
\hline \multirow{2}{*}{ E-resources } & Daily & $\begin{array}{c}\text { Twice a } \\
\text { week }\end{array}$ & $\begin{array}{c}\text { Once a } \\
\text { week }\end{array}$ & Occasionally & Never & $\begin{array}{c}\text { Mean } \\
\text { Scores }\end{array}$ & SD \\
\hline Internet & 293 & 91 & 59 & 31 & 8 & 4.31 & 1.02 \\
& $(60.8 \%)$ & $(18.9 \%)$ & $(12.2 \%)$ & $(6.4 \%)$ & $(1.7 \%)$ & & \\
Online Databases & 137 & 138 & 127 & 65 & 14 & 3.66 & 1.11 \\
& $(28.4 \%)$ & $(28.6 \%)$ & $(26.3 \%)$ & $(13.5 \%)$ & $(2.9 \%)$ & & \\
OPAC & 77 & 185 & 119 & 63 & 36 & 3.43 & 1.13 \\
& $(16.0 \%)$ & $(38.4 \%)$ & $(24.7 \%)$ & $(13.1 \%)$ & $(7.5 \%)$ & & \\
E-Journals & 74 & 136 & 166 & 91 & 14 & 3.34 & 1.04 \\
& $(15.4 \%)$ & $(28.2 \%)$ & $(34.4 \%)$ & $(18.9 \%)$ & $(2.9 \%)$ & & \\
E-books & 65 & 119 & 151 & 122 & 25 & 3.16 & 1.10 \\
& $(13.5 \%)$ & $(24.7 \%)$ & $(31.3 \%)$ & $(25.3 \%)$ & $(5.2 \%)$ & & \\
CD-ROM & 22 & 99 & 137 & 114 & 109 & 2.61 & 1.18 \\
& $(4.6 \%)$ & $(20.5 \%)$ & $(28.4 \%)$ & $(23.7 \%)$ & $(22.7 \%)$ & & \\
Total & & & & & & 3.42 & 1.10 \\
\hline
\end{tabular}


Table 3 reveals that the Internet $(\bar{x}=4.31)$, OPAC $(\bar{x}=3.43)$, Online databases $(\bar{x}=3.66)$, e-journal $(\bar{x}=3.34)$, e-books $(\bar{x}=3.16)$ were frequently utilized while CD-ROM ( $\bar{x}=2.61)$ was not frequently used by the respondents. This result is expected because being private institutions, postgraduate students have access to electronic information resources which is one of the major attractions to the institutions. This could explain why the e-resources are frequently used by the postgraduate students. The CD-ROM is a technology that is being gradually replaced by newer ones in most academic institutions. These days, online databases are available and fast replacing CD-ROM databases which could explain why the frequency of its use by the respondents is low.

\subsection{The Level of Information Literacy Skills of Postgraduate Students}

To ascertain the level of information literacy skills of the respondents, various options were provided which the respondents were requested to indicate the ones acceptable to them. The average mean score and the standard deviation are indicated in Table 4

As shown in Table 4 the information literacy skills level of the respondents is high. This is depicted by the average mean score of 3.23 and standard deviation of 0.71 . In all, the respondents were most skilled in 'ability to initiate how and where to find needed information $(\bar{x}=3.28)$; ability to locate information sources $(\bar{x}=3.28)$ which ranked highest by the mean score rating and was followed by; 'ability to select the information that is most appropriate to needs ( $\bar{x}$ $=3.27)$; and ability to select search strategies by date, subject and language $(\bar{x}=$ 3.27). On the average, the respondents were skilled in areas such as: being able to improve their information literacy skill by learning from information problem solving $(\bar{x}=3.26)$; being able to use many resources at the same time to make a research $(\bar{x}=3.25)$; being able to use information to answer questions and/or solve problems $(\bar{x}=3.23)$. As indicated in the table, the respondents were least skilled in areas such as: being able to define needed information $(\bar{x}=3.20)$; being able to organize information to present a sound central idea supported by relevant material in a logical order $(\bar{x}=3.19)$ and lastly, in ability to identify different sources of information $(\bar{x}=3.13)$

\subsection{The Relationship between Information Literacy Skills and Electronic Resources Use by Postgraduate Students}

To test the hypothesis and analyze the data, a Pearson Product Moment Correlation (PPMC) was employed. The analysis procedure involves pooling respondents' scores on each items measuring information literacy skills to arrive at the composites score; the same procedure was applied for e-resources use. A relationship test was then carried out by associating both information literacy skills and e-resources use, the analysis result is summarized and presented in Table 5.

In Table 5, the analysis result presented indicates that there is a significant 
positive correlation between information literacy skills and e-resources use ( $r$ $(480)=0.28, p<0.05)$. Based on the finding, information literacy skills of postgraduate students increase their use of electronic resources. In other words, a direct relationship exists between information literacy skills and e-resources use among postgraduates students in South-West, Nigeria. Therefore, the null hypothesis which states that there is no significant relationship between information literacy skills and e-resources use among post graduates students in private universities in South-West, Nigeria is rejected and the alternative is accepted.

Table 4. Information literacy skills of the respondents.

\begin{tabular}{|c|c|c|c|c|c|c|c|c|c|c|c|}
\hline $\mathrm{S} / \mathrm{N}$ & Information Literacy Skills & VHL & $\%$ & $\mathrm{HL}$ & $\%$ & LL & $\%$ & VLL & $\%$ & Mean & SD \\
\hline 1 & $\begin{array}{l}\text { I can initiate how and where to find the } \\
\text { information I need }\end{array}$ & 199 & 41.3 & 222 & 46.1 & 51 & 10.6 & 8 & 1.7 & 3.28 & 0.72 \\
\hline 2 & I find it easy to locate information sources & 179 & 37.1 & 260 & 53.9 & 36 & 7.5 & 6 & 1.2 & 3.28 & 0.66 \\
\hline 3 & $\begin{array}{l}\text { I can select the information that is most } \\
\text { appropriate to my needs }\end{array}$ & 191 & 39.6 & 234 & 48.5 & 53 & 11.0 & 4 & 0.8 & 3.27 & 0.68 \\
\hline 4 & $\begin{array}{l}\text { I have the ability to select search } \\
\text { strategies by date, subject and language }\end{array}$ & 180 & 37.3 & 254 & 52.7 & 44 & 9.1 & 3 & 0.6 & 3.27 & 0.65 \\
\hline 5 & $\begin{array}{l}\text { I can improve my information literacy skill } \\
\text { by learning from my information problem } \\
\text { solving experience }\end{array}$ & 191 & 39.6 & 234 & 48.5 & 50 & 10.4 & 7 & 1.5 & 3.26 & 0.70 \\
\hline 6 & $\begin{array}{l}\text { I have the ability to use many resources at } \\
\text { the same time to make a research }\end{array}$ & 172 & 35.7 & 260 & 53.9 & 44 & 9.1 & 5 & 1.0 & 3.25 & 0.66 \\
\hline 7 & $\begin{array}{l}\text { I have the ability to use information to } \\
\text { answer questions and/or solve problems }\end{array}$ & 195 & 40.5 & 212 & 44.0 & 65 & 13.6 & 10 & 2.1 & 3.23 & 0.76 \\
\hline 8 & $\begin{array}{l}\text { The quality of my information } \\
\text { seeking process and its products } \\
\text { can be criticized by me }\end{array}$ & 177 & 36.7 & 245 & 50.8 & 50 & 10.4 & 9 & 1.9 & 3.23 & 0.71 \\
\hline 9 & I have the capability to evaluate www sources & 187 & 38.8 & 223 & 46.3 & 68 & 14.1 & 4 & 0.8 & 3.23 & 0.71 \\
\hline 10 & $\begin{array}{l}\text { I have the capability to organize, } \\
\text { apply and communicate information } \\
\text { to others }\end{array}$ & 178 & 36.9 & 239 & 49.6 & 56 & 11.6 & 8 & 1.7 & 3.22 & 0.71 \\
\hline 11 & $\begin{array}{l}\text { I can introduce search strategies } \\
\text { using Boolean logic and keywords }\end{array}$ & 181 & 37.6 & 229 & 47.5 & 58 & 12.0 & 12 & 2.5 & 3.21 & 0.71 \\
\hline 12 & $\begin{array}{l}\text { I can synthesize newly gathered } \\
\text { information with previous information }\end{array}$ & 186 & 36.8 & 220 & 45.6 & 65 & 13.5 & 9 & 1.9 & 3.21 & 0.74 \\
\hline 13 & $\begin{array}{l}\text { I can synthesize and build upon } \\
\text { existing information }\end{array}$ & 178 & 36.9 & 232 & 48.1 & 63 & 13.1 & 8 & 1.7 & 3.21 & 0.73 \\
\hline 14 & I can define the information I need & 162 & 33.6 & 238 & 49.4 & 54 & 11.2 & 17 & 3.5 & 3.20 & 0.80 \\
\hline 15 & $\begin{array}{l}\text { I can determine the authoritativeness, } \\
\text { correctness and reliability of the } \\
\text { information sources }\end{array}$ & 171 & 35.5 & 233 & 48.3 & 73 & 15.1 & 4 & 0.8 & 3.19 & 0.71 \\
\hline 16 & $\begin{array}{l}\text { I can organize information to present a } \\
\text { sound central idea supported by } \\
\text { relevant material in a logical order }\end{array}$ & 170 & 35.3 & 236 & 49.0 & 67 & 13.9 & 8 & 7.1 & 3.18 & 0.73 \\
\hline \multirow[t]{2}{*}{17} & $\begin{array}{l}\text { I have the ability to identify different sources } \\
\text { of information }\end{array}$ & 162 & 33.6 & 237 & 49.2 & 54 & 11.2 & 25 & 5.2 & 3.13 & 0.82 \\
\hline & Total & & & & & & & & & 3.23 & 0.71 \\
\hline
\end{tabular}

Very High Level, High Level, Low Level, Very Low Level. 
Table 5. PPMC of information literacy skills and electronic resources use.

\begin{tabular}{ccccccc}
\hline Variables & $\mathrm{N}$ & $\mathrm{M}$ & $\mathrm{SD}$ & $\mathrm{df}$ & $\mathrm{r}$ & $\mathrm{p}$-val \\
\hline Information Literacy Skills & 482 & 54.83 & 6.53 & & & \\
E-resources Use & 482 & 61.55 & 7.68 & & & 0.28 \\
\hline
\end{tabular}

$\mathrm{r}(480)=0.28, \mathrm{p}<0.05$.

\section{Conclusion and Recommendations}

Electronic resources utilization in today's world of exponential growth of knowledge has been highly promoted through the advancement in information and communication technology in recent years. Use of electronic resources provides access to current information and thereby improves students' academic performance. Based on the findings of this study; the level of information literacy skills possessed by an individual plays a significant role in determining postgraduate students' degree of electronic resources use. The findings show that people's ability to discover the need for information as well as search skills predict their level of electronic resources use in the academic environment. The teaching of information literacy skills to postgraduate students should be promoted to ensure high level of usage of the resources.

\section{Conflicts of Interest}

The authors declare no conflicts of interest regarding the publication of this paper.

\section{References}

[1] Abubakar, D. and Adetimirin, A. (2015) Influence of Computer Literacy on Postgraduates' Use of E-Resources in Nigerian University libraries. Library Philosophy and Practice (E Journal), Paper 1207.

http://digitalcommons.unl.edu.libphilprac.1207

[2] IFLA (2012) Key Issues for E-Resources Collection Development: A Guide for Libraries.

http://www.ifla.org/publications/key-issues-for-e-resource-collection-developmenta-guide-for-libraries

[3] Shaibu, A.S. and Mohammed, M.K. (2017) Computer Self-Efficacy and Use of Electronic Resources by Students in Nigerian University Libraries. Journal of Applied Information Science and Technology, 10, 91-99.

[4] Oluwaseye, A.J. and Abraham, A.O. (2013) The Challenges in the Development of Academic Digital Library in Nigeria. International Journal of Educational Research and Development, 2,152-157.

[5] Sharma, S. (2009) Use and Impact of E-Resources at Guru Gobind Singh Indraprastha University (India): A Case Study. Electronic Journal of Academic and Special Librarianship, 10, 69-78.

[6] Secker, J. (2004) Electronic Resources in the Virtual Learning Environment: A Guide for Librarians. Chandos Publishing, Oxford, 53-74. https://doi.org/10.1016/B978-1-84334-059-1.50003-8 
[7] Nemine, E.B. and Torunarigha, Y.D. (2010) Educational Technology. Harinsco Press, Port Harcourt.

[8] Grgic, I.H. (2016) Information Literacy and Open Access in Croatian Academic Libraries. Library Review, 65, 255-266. https://doi.org/10.1108/LR-01-2016-0009

[9] Kodani, L. (2012) Information Literacy for Electronic Resources. PowerPoint Presented at the 17 th Annual Technology Colleges and Community Worldwide Conference. http://creativecommons.org/licenses/by-nc-nd/3.0/us/

[10] Ojedokun, A.A. (2007) Information Literacy for Tertiary Education Students in Africa. Third World Information Services Ltd., Ibadan, 3.

[11] Kumar, S., Ochoa, M. and Edward, M. (2012) Considering Information Literacy Skills and Needs: Designing Library Instruction for the Online Learner. Communication in Information Literacy, 6, 91-106. https://doi.org/10.15760/comminfolit.2012.6.1.120

[12] Imsong, L. and Kharbudon, I.M. (2016) Usage of Electronic-Resources in Academic Libraries and Role of Information Literacy. INFLIBNET Centre, Gandhinagar, 31-35.

[13] Rockman, I.F. (2004) Integrating Information Literacy into the Higher Education Curriculum: Practical Models for Transformation. Jossey-Bass, San Francisco.

[14] Soleymani, M.R. (2014) Investigating the Relationship between Information Literacy and Academic Performance among Students. International Journal of Health Promotion and Education, 3, 95.

[15] Julien, H. (2002) Use of Information. In: Schement, J.R., Ed., Encyclopedia of Communication and Information, Macmillan Reference, New York, 1051-1056.

[16] Bankole, B.A., Ajiboye, A.O. and Otunla (2015) Use of Electronic Information Resources by Undergraduates of Federal University of Agriculture, Abeokuta, Ogun State, Nigeria. International Journal of Digital Library Services, 5, 1-14.

[17] Robles, M. and Braathen, S. (2002) Online Assessment Techniques. Delta Pi Epsilon Journal, 44, 39-49.

[18] Melissa, G. and Don, L. (2007) Attaining Information Literacy: Investigation of the Relationship between Skills Level, Self-Estimate of Skill, and Library Anxiety. Library and Information Science Research, 29, 332-353. https://doi.org/10.1016/j.lisr.2007.04.012

[19] Issa, A.O., Amusa, B. and Daura, U.D. (2009) Effects of Information Literacy Skills on the Use of e-Learning Resources among Students of Ilorin, Kwara State, Nigeria. Library Philosophy and Practice.

[20] Walsh, J. (2013) The Effects of Targeted, Connectivism-Based Information Literacy Instruction on Latino Students Information Literacy Skills and Library Usage Behavior. http://hdl.handle.net/10150/312502

[21] Portman, C. and Rousch, A. (2004) Assessing the Effects of Library Instruction. Journal of Academic Librarianship, 30, 461-465. https://doi.org/10.1016/j.acalib.2004.07.004

[22] Streatfield, D. and Markless, S. (2008) Evaluating the Impact of Information Literacy in Higher Education: Progress and Prospects. Libri, 58, 102-109. https://doi.org/10.1515/libr.2008.012

[23] Ekenna, M. and Mabawonku, I. (2013) Information Retrieval Skills and Use of Library Electronic Resources by University Undergraduates in Nigeria. Information and Knowledge Management, 3, 1-10. 
[24] Xie, H.I. (2007) Shifts in Information-Seeking Strategies in Information Retrieval in the Digital Age. A Planned-Situational Model. Information Research, 12, 1-9.

[25] Omeluzor, S.U., Bamidele, I.A., Onuoha, U.D. and Alarape, A.A. (2013) Information Literacy Skills among Postgraduate Students of Babcock University, Nigeria. International Journal of Innovative Research in Management, 2, 1-18.

[26] Alison, K.A., Kyinji, G.W. and Baziraake, B.B. (2012) Factors Affecting Utilization of Electronic Information Resources. Annals of Library and Information Studies, 59, 90-96.

[27] Bakare, O.D., Owolabi, O.A., Banigboye, O.B. and Bankole, O.M. (2013) Factors Affecting Library by Academic Staff and Students of Federal University of Agriculture. Abeokuta, Ogun State. PNLA Quarterly. http://connection,ebcohost.com/c/articles/86978740/factorsaffecting_library-use-by -academicstaff-students-federal-universityagriculture

[28] Sithole, N. and Chisita, C. and Jagero, N. (2015) Information Literacy Evaluation: A Case Study of the Africa University, Mutare, Zimbabwe. British Journal of Education, Society and Behavioural Science, 9, 341-351.

[29] Oyedapo, R.O. and Ojo, R.A. (2013) A Survey of the Use of Electronic Resources in Hezekiah Oluwasanm Library, Obafemi Awolowo University, Ile-Ife, Nigeria. Library Philosophy and Practice. http://digitalcommons.unl.edu/libphilprac/884

[30] Manda, P.A. (2005) Electronic Resource Usage in Academic and Research Institutions in Tanzania. Information Development, 21, 269-282. https://doi.org/10.1177/0266666905060070

[31] Adeleke, D.S. and Emeahara, E.N. (2016) Relationship between Information Literacy and Use of Electronic Information Resources by Postgraduate Students of the University of Ibadan. Library Philosophy and Practice.

[32] Brown, R. (2000) Social Identity Theory: Past Achievements, Current Problems and Future Challenges. European Journal of Social Psychology, 30, 745-778. https://doi.org/10.1002/1099-0992(200011/12)30:6<745::AID-EJSP24>3.0.CO;2-O 